\title{
Effects of the weaning age of calves on somatic development and on reproductive performance of beef cows
}

\author{
Ricardo Zambarda Vaz¹, José Fernando Piva Lobato²
}

\footnotetext{
1 Pós-Graduação em Zootecnia - Departamento de Zootecnia - Faculdade de Agronomia - UFRGS.

2 Departamento de Zootecnia - Faculdade de Agronomia - UFRGS.
}

\begin{abstract}
This study evaluated body development and reproductive performance of beef cows whose calves were submitted to early weaning (76 days of age), or conventional weaning (148 days of age). It was used 141 Braford cows that calved in 2004, 2005, and 2006 to evaluate weight at calving at 76 days, weight at calving at 148 days, weight at the beginning and end of the breeding season, variation of the average daily weight, body condition, pregnancy rate, and calving interval. Dams of calves weaned at 148 days of age showed daily weight gain higher body weight and better body condition at 148 days of age. The weights at the end of breeding season and average weight gain during the breeding season were higher in early weaning cows than in conventional cows. Pregnancy rate of early weaning cows $(86.34 \%)$ was higher than those submitted to weaning at conventional age $(55.45 \%)$. Pasture interval was similar among early weaning cows and conventional weaning cows. The best benefit on reducing weaning age in pregnancy rate was in primiparous cows. There was significant interaction between weaning age and the year for calving interval and milk production. The early weaning of calves carried out at 76 days of age allows cows to better weight recovery in the post-weaning and breeding periods, improving their body condition and consequently increasing pregnancy rate regarding to cows whose calves suckled until 148 days of age.
\end{abstract}

Key Words: body condition, Braford, conventional weaning, early weaning, weight gain

\section{Efeitos da idade ao desmame no desenvolvimento somático e desempenho reprodutivo de vacas de corte}

\begin{abstract}
RESUMO - Avaliaram-se o desenvolvimento somático e o desempenho reprodutivo de vacas de corte cujos bezerros foram submetidos ao desmame precoce (76 dias de idade) ou à idade convencional (aos 148 dias de idade). Foram utilizadas 141 vacas Braford paridas nos anos de 2004, 2005 e 2006 para avaliação dos pesos ao parto, aos 76 dias, aos 148 dias, ao início e fim do período reprodutivo, da variação de peso médio diário, da condição corporal, da taxa de prenhez e do intervalo de partos. As vacas mães dos bezerros desmamados aos 148 dias tiveram maior ganho médio diário, maior peso e melhor condição corporal aos 148 dias. O peso ao fim do período reprodutivo e o ganho médio diário durante o período reprodutivo foram maiores nas vacas do desmame precoce. A taxa de prenhez das vacas do desmame precoce $(86,34 \%)$ também foi superior à das vacas submetidas ao desmame em idade convencional $(55,45 \%)$. O intervalo de parto foi semelhante entre vacas do desmame precoce e aquelas do desmame em idade convencional. O maior benefício da redução da idade de desmame na taxa de prenhez observado foi nas vacas primíparas. Houve interação significativa entre a idade de desmame e o ano para intervalo de partos e produção de leite. O desmame precoce dos bezerros realizado aos 76 dias de idade permite às vacas maior recuperação do peso nos períodos pós-desmame e reprodutivo, melhorando sua condição corporal e aumentando a taxa de prenhez em relação às vacas mantidas em amamentação até os 148 dias de idade.
\end{abstract}

Palavras-chave: Braford, condição corporal, desmame convencional, desmame precoce, ganho de peso

\section{Introduction}

Breeding herd productive efficiency significantly influences productivity indicators (Beretta et al., 2002), therefore the so-called "traditional" systems are less productive because they have worse reproductive indexes and higher steer market ages (Pötter et al., 2000).
The development of beef cows and their reproductive performance are affected by management practices, health care, and nutritional levels to which they are submitted, which are clearly seen in southern Brazil, where most beef cattle operations are based on native pastures, the main nutritional source of those herds (Restle et al., 2001). 
The lack of proper management practices and excessive stocking rates reduce weight gain resulting in low pregnancy rates (Moojen et al., 1994; Quadros \& Lobato, 1996; Gottschall \& Lobato, 1996; Simeone \& Lobato, 1996; Fagundes et al., 2003).

Costa et al. (1981) and Pötter \& Lobato (2004) showed that productive and reproductive indexes can be improved by introducing cultivated pastures in beef production systems but the use of these kind of pastures may not be practical or economically feasible for breeding herds in most commercial beef systems (Restle et al., 1998).

Lactation affects cow reproductive performance. Studies suggest that anestrus during lactation results from the nutritional status of the cow and from a possible endocrine suppression caused by lactation. The mere presence of the calf, even with no direct effect of suckling, may trigger this inhibitory effect (Short et al., 1990).

The aim of early weaning is to make cows recover their body weight and body condition - even when submitted to feed restriction - thereby improving their reproductive efficiency (Moojen et al., 1994; Pascoal \& Vaz, 1997; Restle et al., 2001; Fagundes et al., 2003; Almeida \& Lobato, 2004).

The objective of this study was to evaluate the effects of calf early weaning on the development, body condition, and reproductive efficiency of Braford cows as primiparous cows at three years of age, and during the next two breeding seasons.

\section{Material and Methods}

The experiment was carried out at Granja Itú, Itaqui, Rio Grande do Sul, Brazil, (latitude 29 $12^{\prime}$ South and longitude 55 36' West), from September 2004 to May 2007. This region is characterized by the presence of rolling hills, with deep, naturally-acid soils with intermediate surface texture, classified as red podzolic latosol (EMBRAPA, 1999), and the climate is subtropical, according to classification of Köppen (Moreno, 1961).

Initially, it was used 141 primiparous Bradford cows at the age of 36 months, and the following calf weaning ages were applied: early weaning, for cows whose calves were weaned approximately at 76 days post-calving, and conventional weaning, for cows whose calves were weaned approximately at 148 days post-calving.

The weaning ages presented different numbers of replicates, according to the different breeding seasons: 71, 63 and 51, and 70,28 and 18 for the dams of early weaning calves and dams of conventional weaning calves during 2004/2005, 2005/2006, and 2006/2007 seasons, respectively. As the study started with primiparous cows at three years of age (2004), which then calved at four (2005) and five (2006) years of age, these two effects are completely confounding, and they were considered as the joint effect of calf birth year and cow age. Empty cows were excluded.

Cows from the two weaning groups were always managed as a single group, differing only at the calf weaning age. Between the first (Sep., 2004) and the second calving (Sep., 2005), cows were managed on native pasture at a stocking rate of $320 \mathrm{~kg}$ live weight/ha.

From the second calving until the date of conventional calf weaning age, as applied in this season, cows grazed on Brachiaria brizantha cv Marandu. After weaning, cows returned to native pastures, where they remained until the third calving (September, 2006), when they grazed on Brachiaria Humidicola (Rendle) schweick until conventional weaning date (March 5th, 2007). Therefore, during the second (December 10th, 2005 to February 2nd, 2006) and third (December 15th , 2006 to February 5th, 2007 ) breeding season, cows grazed on B. brizantha and B. humidicola, respectively.

Cows were naturally bred to sires previously approved by the libido test and andrological exam at a 1 bull : 25 cows ratio. Ultrasound pregnancy diagnosis was carried out 30 days after the end of the breeding seasons.

Forage samples were analyzed for crude protein (CP) and neutral detergent fiber (NDF) contents according to the techniques described by the AOAC (1984) at the Laboratório de Nutrição Animal of the Escola de Agronomia, UFRGS.

Early weaning was gradually conducted from December to February as the calves reached 60 and 70 days of age, except those born in 2004, which were weaned together on December 26th, 2004, with an average age of 91 days. Therefore, the average weaning age during the three years of observation was 76 days. Conventional weaning during those three years was carried out on single dates at the beginning of March (March 5th, 2005, March 3rd, 2006, and March 6th, 2007) aiming at allowing cows to recover body weight and build reserves before the winter (Lobato, 2003).

Cows were weighed within the first 24 hours postcalving, on early and conventional weaning dates, at the beginning and end of the breeding season, and every 28 days during the breeding season.

Daily weight gain was determined as the weight difference between weighings. When animals were weighted, their body condition score was evaluated (BCE; Lowman et al., 1973) in a scale of 1 to 5 , where $1=$ very thin and 5 = very fat.

Calving interval $(\mathrm{CI})$ of cows that calved in the spring of 2005 and 2006 was determined as the difference in days 
between calving dates of 2004-2005 and 2005-2006, respectively.

Cow milk production was estimated on early weaning dates in 2005 and 2006 as the difference in calf weight before and after suckling (Melton et al., 1967). Calves were separated from their dams from 12:00 pm to 6:00 pm, when they were reunited to the dams and allowed to suckle, aiming at emptying the udder. After that, calves were again separated from their dams until the next morning, or 12 hours of fasting, and then were weighed, allowed to suckle until finishing, and weighed again. Milk production during the period and 24 hours was estimated by the weight difference between calf weighings.

During the experimental period, cows had free access to a mineral mixture containing $80 \mathrm{ppm}$ phosphorus, consisting of sodium chloride and dicalcium orthophosphate. Animals were vaccinated against foot and mouth diseases and clostridiosis at the required and recommended dates. Endoparasites were controlled by strategic administration of broad-spectrum deworming products, and ectoparasites (ticks, grubs, and screwworms) by specific products.

A completely randomized experimental design in a $2 \times 2 \times 3$ factorial arrangement (two weaning ages $\times$ two calf sexes $\times$ three years of observation) was applied. The results were submitted to analysis of variance and to the F-test. The following mathematical model was used for the analyses:

$\mathrm{Y}_{\mathrm{ijkl}}=\mu \pm \mathrm{W}_{\mathrm{i}} \pm \mathrm{S}_{\mathrm{j}} \pm(\mathrm{W} * \mathrm{~S})_{\mathrm{ij}} \pm \mathrm{R}_{\mathrm{k}}(\mathrm{W} * \mathrm{~S})_{\mathrm{ij}} \pm \mathrm{Y}_{1} \pm\left(\mathrm{W}^{*} \mathrm{Y}\right)_{\mathrm{il}} \pm$ $(\mathrm{Y} * \mathrm{~S})_{1 \mathrm{j}} \pm(\mathrm{W} * \mathrm{~S} * \mathrm{Y})_{\mathrm{ij} 1} \pm \mathrm{O}_{\mathrm{ijk} 1}$

where: Yijkl $=$ dependent variables; $\mu$ - mean of all observations; $\mathrm{W}_{\mathrm{i}}=$ effect of the $\mathrm{i}^{\text {th }}$ weaning age, with $\mathrm{i}=1$ (early weaning); 2 (conventional weaning); $\mathrm{S}_{\mathrm{j}}=$ effect of $\mathrm{j}^{\text {th }}$ calf sex, with $\mathrm{j}=1$ (male); $2=($ female $) ; \mathrm{W}^{*} \mathrm{~S}_{\mathrm{ij}}=$ effect of the interaction of the $i^{\text {th }}$ weaning age vs. effect of the $\mathrm{k}^{\text {th }}$ calf sex; $\mathrm{R}_{\mathrm{k}}\left(\mathrm{W}^{*} \mathrm{~S}\right)_{\mathrm{ij}}=$ effect of the $\mathrm{k}^{\text {th }}$ animal with the interaction ${ }_{i}{ }^{\text {th }}$ weaning age vs. $j^{\text {th }}$ calf sex; $Y_{1}=$ effect of the $1^{\text {th }}$ year and cow age; $\mathrm{W}^{*} \mathrm{Y}_{\mathrm{il}}=$ effect of the interaction $\mathrm{i}^{\text {th }}$ weaning age vs. effect of the $1^{\text {th }}$ year and cow age set; $\mathrm{W} * \mathrm{~S} * \mathrm{Y}_{\mathrm{ijl}}=$ effect of the $\mathrm{k}^{\text {th }}$ animal with the interaction $\mathrm{i}^{\text {th }}$ weaning age vs. $\mathrm{j}^{\text {th }}$ calf sex vs. effect of the $1^{\text {th }}$ year and cow age set; $\hat{O}_{\mathrm{ijkl}}=$ residual error.

The interactions $(\mathrm{W} * \mathrm{~S})_{\mathrm{ij} ;}(\mathrm{Y} * \mathrm{~S})_{\mathrm{lj} ;} ;(\mathrm{W} * \mathrm{~S} * \mathrm{Y})_{\mathrm{ijl}}$ presented low magnitude, therefore they were removed from the final statistical model. Analyses were carried out with the aid of GLM procedures. Data were analyzed using SAS statistical package, version 6.08 (SAS, 1997), adopting 5\% as maximum significance level. Means were compared by the t-test. The parameter pregnancy rate at different weaning ages was analyzed by the Chi-Square test at 5\% significance level.

\section{Results and Discussion}

The obtained qualitative values of the different pastures (Table 1) are similar to those observed in other studies carried out in the state of Rio Grande do Sul (Freitas et al., 1976; Cerdótes et al., 2004b; Pilau \& Lobato, 2009), slightly varying from each other possibly because of climate diversity and soil fertility in each region.

Except for calving interval, no significant effect of the interaction between weaning age and year on the studied parameters was verified. Therefore, despite of being grouped in the Tables, the results are discussed separately.

Cow weight after 2004 (2005 e 2006) increased $(\mathrm{P}<0.05)$ at calving $(312.6,350.0$, and $432.4 \mathrm{~kg})$, early weaning $(332.2$, $377.95,449.55 \mathrm{~kg})$, and conventional weaning $(337.5,396.7$, and $451.0 \mathrm{~kg}$ ), independently from weaning age, respectively, as cows aged (Table 2; Figure 1).

As previously mentioned, the effects of year and cow age are confounding. This means that the effect of year has increased due to the effect of cow age, which are then considered as a single set. Cow weight increase was expected, mainly as a function of growth. Restle et al. (2001), working with different age classes of cows submitted or not

Table 1 - Forage mass, crude protein and neutral detergent fiber percentages of the pastures used during the experimental period

\begin{tabular}{|c|c|c|c|c|c|c|c|}
\hline & \multirow[b]{2}{*}{ Period } & \multicolumn{2}{|c|}{ Forage mass $(\mathrm{kg} / \mathrm{ha} \mathrm{DM})$} & \multicolumn{2}{|c|}{ Crude protein $(\%)$} & \multicolumn{2}{|c|}{ Neutral detergent fiber $(\%)$} \\
\hline & & Mean & Variation & Mean & Variation & Mean & Variation \\
\hline Natural pasture & Sep-Dec/2004 & 1640 & $1430-2120$ & 8.60 & $6.5-10.1$ & 67.8 & $63.9-72.4$ \\
\hline Natural pasture & Jan-Apr/2005 & 1550 & $1430-1830$ & 6.05 & $5.85-6.45$ & 72.1 & $69.9-73.2$ \\
\hline Natural pasture & May-Aug/2005 & 1430 & $1210-1550$ & 7.07 & $5.95-7.65$ & 71.3 & $70.2-72.2$ \\
\hline Natural pasture & Sep-Oct/2005 & 1330 & $1270-1390$ & 10.66 & $10.5-10.8$ & 65.5 & $62.9-68.1$ \\
\hline B. brizantha & Oct-Dec/2005 & 2120 & $1890-2350$ & 6.97 & $6.57-7.17$ & 70.0 & $67.4-72.4$ \\
\hline B. brizantha & Jan-Mar/2006 & 2450 & $2200-2590$ & 6.50 & $6.44-6.56$ & 71.2 & $70.9-71.4$ \\
\hline Natural pasture & Apr-Ju1/2006 & 1670 & $1530-1890$ & 5.64 & $5.16-6.22$ & 72.9 & $69.3-75.2$ \\
\hline Natural pasture & Aug-Oct/2006 & 1460 & $1320-1590$ & 8.38 & $7.04-9.72$ & 71.7 & $68.3-75.2$ \\
\hline B. humidicola & Oct-Dec/2006 & 2705 & $2540-2870$ & 7.32 & $7.26-7.38$ & 73.9 & $73.4-74.4$ \\
\hline B. humidicola & Jan-Mar/2007 & 3050 & $3080-3730$ & 5.94 & $5.91-5.97$ & 72.2 & $72.0-72.3$ \\
\hline
\end{tabular}


to early weaning, obtained similar results: young cows (three to four years of age) were lighter as compared to mature cows (five to seven years of age), which in turn were not different from cows older than eight years of age. Vieira et al. (2005) worked with Nelore cows and also found that older cows were heavier.

Mean calving weights during the three years of observation were 367.4 and $362.3 \mathrm{~kg}(\mathrm{P}>0.05)$ for cows submitted to early weaning and conventional weaning, respectively. In 2006, cows in the early weaning group presented higher $(\mathrm{P}<0.05)$ calving weight $(441.1 \mathrm{~kg})$ as compared to those in the conventional weaning group (423.7 kg). This weight difference in 2006 is caused by the progressive reduction in the nutritional requirements of the cows, because as cows get older, the lesser is their requirements for growth, consequently the nutrients are headed for maintenance and weight gain, providing better conditions for development and deposition of body reserves. This resulted in a daily weight variation (DWV) of $\pm 0.533 \mathrm{~kg}$ from days 76 to 148 in 2005, and consequent higher calving weight in 2006. On the other hand, in 2005, calving weight of cows submitted to early weaning was not different from those conventionally weaned, probably due to the lower daily weight variation ( $\pm 0.253 \mathrm{~kg}$ ) between days 76 and 148 in the previous year (2004) and the capacity of cows for recovering their body weight before the conventional weaning conducted on March 03, 2006 (Figure 1).

At the time of early weaning, average weights for early and conventionally weaned cows were 386.9 and $386.3 \mathrm{~kg}$, respectively, with no significant differences between weaning ages or years. However, at the time of conventional weaning, weight and average daily weight variation during the period between weanings was higher in cows $(\mathrm{P}<0.05)$ submitted to early weaning (409.3 and $0.353 \mathrm{~kg}$, respectively) relative to those submitted to conventional weaning (381.0 and $-0.092 \mathrm{~kg}$, respectively). The weight difference in favor of the early-weaned cows was observed during the three studied years, and represented 7.30\%, 6.67\%, and $8.12 \%$ for the years 2004, 2005, and 2006, respectively.

Weight increase of the cows submitted to both treatments shows the same trend, demonstrating that the period when the conventionally-weaned cows continue to produce milk restricted their development, particularly as primiparous cows (Figure 1).

The higher average daily weight variation of cows submitted to early weaning during the evaluated years was caused by the suppression of lactation and by the reduction of their requirements, allowing better weight recovery (Lobato et al., 2000; Fagundes et al., 2003). According to the NRC (1996), the energy requirements of lactating cows between 70 and 150 days post-calving are $56 \%$ higher than those that are not producing milk.

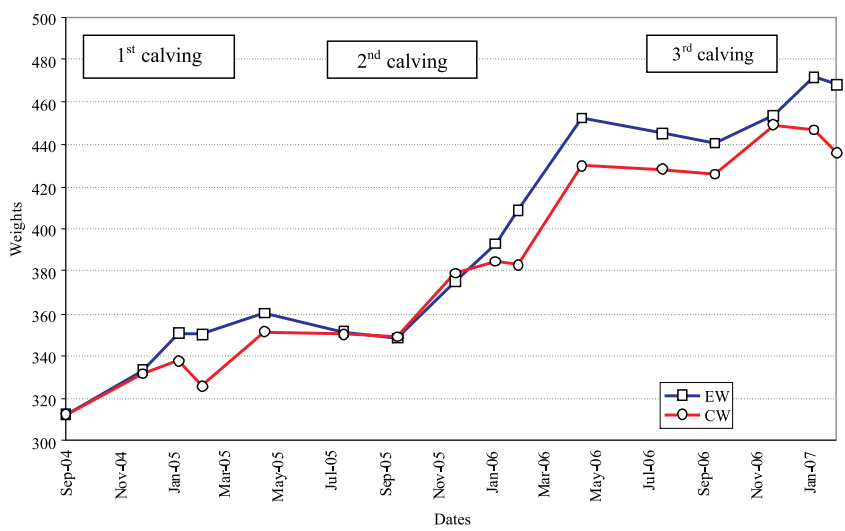

Figure 1-Cow weight evolution from the first calving (September, 2004) until the third conventional weaning (March, 2007) according to calf weaning age.

Table 2 - Mean weight at calving, early weaning, and conventional weaning; average daily weight variation between weanings of cows as a function of year and weaning age

\begin{tabular}{|c|c|c|c|c|c|c|}
\hline \multirow[b]{2}{*}{ Age at weaning } & \multirow[b]{2}{*}{ Year } & \multirow[b]{2}{*}{$\mathrm{N}$} & \multicolumn{3}{|c|}{ Weight, kg } & \multirow[b]{2}{*}{$\begin{array}{l}\text { Daily weight } \\
\text { variation, } \mathrm{kg}\end{array}$} \\
\hline & & & Calving & $\begin{array}{c}\text { Early } \\
\text { weaning }\end{array}$ & $\begin{array}{c}\text { Conventional } \\
\text { weaning }\end{array}$ & \\
\hline \multirow[t]{4}{*}{ Early weaning } & 2004 & 71 & $312.5 \pm 3.3$ & $333.0 \pm 3.3$ & $349.9 \pm 3.7$ & $0.253 \pm 0.033$ \\
\hline & 2005 & 63 & $349.3 \pm 3.6$ & $376.4 \pm 3.4$ & $409.5 \pm 4.1$ & $0.533 \pm 0.038$ \\
\hline & 2006 & 51 & $441.1 \pm 3.9$ & $451.4 \pm 4.0$ & $468.6 \pm 4.4$ & $0.272 \pm 0.040$ \\
\hline & Mean & & $367.6 \pm 2.1$ & $386.9 \pm 2.1$ & $409.3 \pm 2.4 \mathrm{~A}$ & $0.353 \pm 0.022 \mathrm{~A}$ \\
\hline \multirow[t]{5}{*}{ Conventional weaning } & 2004 & 70 & $312.6 \pm 3.3$ & $331.4 \pm 3.3$ & $325.6 \pm 3.7$ & $-0.091 \pm 0.034$ \\
\hline & 2005 & 28 & $350.7 \pm 5.4$ & $379.5 \pm 5.4$ & $383.9 \pm 6.0$ & $0.070 \pm 0.055$ \\
\hline & 2006 & 18 & $423.7 \pm 6.5$ & $447.7 \pm 6.6$ & $433.4 \pm 7.3$ & $-0.227 \pm 0.067$ \\
\hline & Mean & & $362.3 \pm 3.0$ & $386.3 \pm 3.1$ & $381.0 \pm 3.4 \mathrm{~B}$ & $-0.092 \pm 0.031 \mathrm{~B}$ \\
\hline & CV $(\%)$ & & 7.86 & 7.49 & 8.03 & 23.81 \\
\hline
\end{tabular}

A,B - Means followed by different capital letters in the same column are different $(\mathrm{P}<0.05)$ by the F-test.

$\mathrm{CV}=$ Coefficient of variation 
Simeone \& Lobato (1996) obtained higher average daily weight variations when compared to the present study, but it was also observed higher weight variation $(\mathrm{P}<0.01)$ in cows whose calves were submitted to early weaning $(0.410 \mathrm{~kg} /$ day $)$ as compared to those with calves submitted to conventional weaning $(0.015 \mathrm{~kg} /$ day $)$. Lower values were reported by Restle et al. (2001), who worked with cows grazing on native pastures, and found variations of $0.178 \mathrm{~kg} /$ day and $-0.183 \mathrm{~kg} /$ day in cows whose calves were weaned 90 or 210 days post-calving, respectively.

The low weight gain observed in 2004 in the cows of the early weaning group $(0.253 \mathrm{~kg})$ during the period between the weaning ages is a consequence of an atypical year, which presented a long drought period and low rainfall (70 and $14 \mathrm{~mm}$ rain in January and February, respectively). Because of the consequent reduction in the quantity and quality of the native pasture where the cows grazed, as well as the $320-\mathrm{kg}$ stocking rate applied, performance, milk production, and weight at calf weaning were negatively affected (Vaz \& Lobato, 2010).

The low average quality of the native pastures where the cows grazed after calving is demonstrated by the crude protein and neutral detergent fiber contents of 8.60 and $67.83 \%$ between September and December, 2004, and of 6.05 and $72.1 \%$ between January and April, 2005, respectively (Table 1). Under these conditions, lactating cows do not present good reproductive performance (Almeida et al., 2002) and do not supply their calves with enough milk to promote proper development (Restle et al., 2004).

When there are excessive stoking rates and changes in forage amount and quality that reduce diet selection, reproductive performance is worsened (Simeone \& Lobato, 1996; Fagundes et al., 2003), conception during the breeding season is delayed (Pötter \& Lobato, 2004), and milk production is reduced (Quadros \& Lobato, 1997), as well as calf weaning weight (Quadros \& Lobato, 1997; Simeone \& Lobato, 1998). Simeone \& Lobato (1996) and Pötter \& Lobato (2004) obtained higher pregnancy rates when more than $2500 \mathrm{~kg} \mathrm{DM} /$ ha were offered.

Another factor to be considered is that the cows that calved in 2004 for the first time were at three years of age. Growing females have their requirements increased by lactation, which result in lower subsequent development and reproductive performance if feeding conditions are not adequate (Costa et al, 1981; Simeone \& Lobato, 1996; Fagundes et al., 2003). There are physiological changes as the animal ages, promoting optimal performance when the animal is a mature animal (Cobuci et al., 2000). Lobato \& Vaz (2006) emphasized the high nutritional requirements of cows, independently from the reproductive cycle phase, because nutritional maintenance, growth, lactation, and reproduction requirements overlap during the year.

Body condition score increased $(\mathrm{P}<0.05)$ throughout the year as cow aged. Restle et al. (2001) verified that for weaning calves at 90 days of age, the body condition score was lower in young cows (3.0 points), higher in mature cows (3.7 points), and reduced again to an intermediate score of 3.2 points in old cows. Those authors observed a similar body condition score behavior in cows weaned at 210 days, which, however, presented lower values.

Average body condition score was similar between cows from both treatments: 3.31 and 3.32 points at early weaning of cows of the early weaning and conventional weaning groups, respectively. However, at the time of conventional weaning, early-weaned cows presented significantly higher body condition score (3.78 points)

Table 3 - Average body condition score at calving of early or conventionally weaned cows according to age at weaning and year

\begin{tabular}{|c|c|c|c|c|c|}
\hline \multirow[b]{2}{*}{ Age at weaning } & \multirow[b]{2}{*}{ Year } & \multirow[b]{2}{*}{ Number } & \multicolumn{3}{|c|}{ Body condition, points } \\
\hline & & & Calving & Early weaning & $\begin{array}{c}\text { Conventional } \\
\text { weaning }\end{array}$ \\
\hline \multirow[t]{4}{*}{ Early weaning } & 2004 & 71 & $2.32 \pm 0.03$ & $2.82 \pm 0.04$ & $3.15 \pm 0.04$ \\
\hline & 2005 & 63 & $2.92 \pm 0.04$ & $3.20 \pm 0.04$ & $3.89 \pm 0.05$ \\
\hline & 2006 & 51 & $3.83 \pm 0.04$ & $3.90 \pm 0.04$ & $4.29 \pm 0.05$ \\
\hline & Mean & & $3.02 \pm 0.02$ & $3.31 \pm 0.02$ & $3.78 \pm 0.03 \mathrm{~A}$ \\
\hline \multirow[t]{5}{*}{ Conventional weaning } & 2004 & 70 & $2.33 \pm 0.03$ & $2.82 \pm 0.04$ & $2.74 \pm 0.04$ \\
\hline & 2005 & 28 & $2.93 \pm 0.05$ & $3.22 \pm 0.06$ & $3.30 \pm 0.07$ \\
\hline & 2006 & 18 & $3.71 \pm 0.06$ & $3.92 \pm 0.07$ & $3.89 \pm 0.08$ \\
\hline & Mean & & $2.99 \pm 0.03$ & $3.32 \pm 0.03$ & $3.31 \pm 0.04 \mathrm{~B}$ \\
\hline & CV (\%) & & 9.78 & 9.67 & 9.85 \\
\hline
\end{tabular}

A,B - Means followed by different capital letters in the same column are different $(\mathrm{P}<0.05)$ by the F-test. $\mathrm{CV}=$ Coefficient of variation . 
relative to those submitted to conventional weaning (3.31 points). After the early weaning date, the cows in this group increased their body weight and body condition (Tables 2 and 3), whereas those in the conventional weaning group lost body weight and body condition.

This increase in cow body condition is important, as cows are in the breeding season, and increases in weight gain and body condition in this period are essential to obtain good reproductive indexes (Simeone \& Lobato, 1996; Lobato et al., 2000; Restle et al., 2001). The maintenance of body weight and condition in cows with low weight and body condition results in poor reproductive performance. Lobato et al. (2000) associate these facts to a combination of lower availability and a possible lower digestibility of native pastures at the end of their cycle and the maintenance of lactation. Clutter \& Nielsen (1987) stated that when nutritional conditions are not adequate, cows tend to maintain milk production by mobilizing body reserves.

Cow body condition is influenced by the supplied nutritional levels and their nutritional requirements, and it is a result of cow weight gain (Table 4). Therefore, the higher the weight gain, the higher the recovery of muscle accretion and fat deposition.

Body condition score is a good indicator of muscle development and subcutaneous fat deposition, which are correlated with reproductive performance (Lemenager et al., 1980; Osoro, 1986). Restle et al. (2001) observed that 87.9\% of cows with body condition scores between 3 and 4 were those submitted to early weaning, while only $41.2 \%$ of those that were conventionally weaned presented those scores.

According to Rovira (1996), the worse the body condition of the cows, the earlier they should be weaned in order to improve their physiological conditions and pregnancy rates. The higher weight gain and the better body condition of cows whose calves were submitted to early weaning have a direct effect on their subsequent reproductive performance (Moojen et al., 1994; Simeone \& Lobato, 1996; Lobato et al., 2000; Restle et al., 2001; Almeida et al., 2002).

The effect of calf weaning age on mean daily weight variation during the breeding season, and weight at the end of the season was significant. Cows weaned at 76 days post-calving presented superior body weight at the end of the breeding season (405.7 vs $395.4 \mathrm{~kg}$ ) and higher daily weight variation $(0.261 \mathrm{vs} 0.096 \mathrm{~kg})$ during the breeding season as compared to those weaned 148 post-calving.

The average pregnancy rate during the three years of the study of early weaning cows was $86.34 \%$, which was significantly higher $(\mathrm{P}<0.05)$ than that of conventional weaning cows, of $55.45 \%$ (Table 5). These results are consistent with those obtained by Barcellos \& Lobato (1992), Moojen etal.(1994), Simeone \& Lobato, (1996); Restle et al. (2001), and Almeida et al. (2002), who found that cows submitted to early weaning presented higher pregnancy rates as compared to conventionally-weaned cows.

In the present study, 104 and 57 female calves from early weaning and conventional cows, and 81 and 57 male calves from early weaning and conventional cows, respectively, were born in the spring of 2004 (September 07 to October 15), 2005 (October 05 to December 01), and 2006 (October 10 to November 25). These calves were the offspring of primiparous, second-calving, and third-calving cows. The highest difference in pregnancy rate in favor of cows weaned at 76 days $(\mathrm{P}<0.05)$ occurred in the first year of observations, when cows calved for the first time at three years of age. In the subsequent years, cows from both groups presented similar reproductive behavior, because conventional weaning was carried out in the beginning of

Table 4 - Mean initial and final body weight, and daily weight variation of cows during the breeding seasons, according to age at weaning and year

\begin{tabular}{|c|c|c|c|c|c|}
\hline \multirow[b]{2}{*}{ Age at weaning } & \multirow[b]{2}{*}{ Year } & \multirow[b]{2}{*}{ Number } & \multicolumn{3}{|c|}{ Weight breeding season, $\mathrm{kg}$} \\
\hline & & & Initial & Final & $\begin{array}{l}\text { Daily weight } \\
\text { variation, } \mathrm{kg}\end{array}$ \\
\hline \multirow[t]{4}{*}{ Early weaning } & 2004 & 71 & $336.7 \pm 3.4$ & $350.6 \pm 3.5$ & $0.197 \pm 0.030$ \\
\hline & 2005 & 63 & $374.5 \pm 3.8$ & $394.7 \pm 3.9$ & $0.347 \pm 0.033$ \\
\hline & 2006 & 51 & $454.1 \pm 4.0$ & $471.9 \pm 4.1$ & $0.240 \pm 0.035$ \\
\hline & Mean & & $388.5 \pm 2.2$ & $405.7 \pm 2.2 \mathrm{~A}$ & $0.261 \pm 0.019 \mathrm{~A}$ \\
\hline \multirow[t]{5}{*}{ Conventional weaning } & 2004 & 70 & $334.5 \pm 3.4$ & $337.2 \pm 3.5$ & $0.038 \pm 0.030$ \\
\hline & 2005 & 28 & $380.9 \pm 5.5$ & $385.2 \pm 5.7$ & $0.073 \pm 0.048$ \\
\hline & 2006 & 18 & $450.7 \pm 6.7$ & $463.7 \pm 6.9$ & $0.176 \pm 0.059$ \\
\hline & Mean & & $388.7 \pm 3.1$ & $395.4 \pm 3.2 \mathrm{~B}$ & $0.096 \pm 0.027 \mathrm{~B}$ \\
\hline & CV $(\%)$ & & 7.52 & 7.57 & 21.07 \\
\hline
\end{tabular}

A,B - Means followed by different capital letters in the same column are different $(\mathrm{P}<0.05)$ by the F-test.

$\mathrm{CV}=$ Coefficient of variation 
March. This allowed cows to store body reserved during the fall, before the winter, when forage allowance and quality sharply decreased (Lobato \& Vaz, 2006).

Lobato et al. (2000), also working with primiparous cows at 36 months of age, but post-calving grazing on winter-spring improved pastures, did not find any differences in the reproductive performance between those submitted or not to early weaning, with $100 \%$ and $89.5 \%$ pregnancy rates, respectively. Those authors emphasized the importance of adequate body weight and body condition at the beginning of the breeding season as a result of supplying the cows good nutritional levels, thereby preventing significant differences in pregnancy rates among cows.

Restle et al. (2001) demonstrated the effect of the relationship between cow age and response to early weaning on pregnancy rate. They found that pregnancy rates were significantly higher in young cows at three and four years of age submitted to early weaning (63.64 vs. $12.50 \%$ ), not significantly different in mature cows at five to seven years of age ( 70.59 vs. $53.33 \%$ ), and again significantly higher in cows older than eight years of age (66.67 vs. $35.71 \%$ ).

According to Almeida et al. (2002), despite the improvement of reproductive indexes when early weaning is used, the indexes themselves may not allow beef cattle production to be economically feasible. The authors conclude focusing on the importance of cow body weight and body condition at weaning, because, when negatively influenced by previous poor nutritional management (cows in that study grazed on low availability native pastures, with $730.5 \mathrm{~kg} \mathrm{DM} / \mathrm{ha}$ ), reproductive performance is compromised. Under excessive stocking densities, which determine lower forage availability and consequent lower body weight, cows present low reproductive indexes (Moojen et al..1994; Simeone \& Lobato, 1996; Fagundes et al., 2003).

Body condition at calving and body weight at the beginning of the breeding season increased along the studied years. During 2005/2006 and 2006/2007, both early weaning and conventional weaning cows presented adequate body weight and body condition to allow them to get pregnant in the next breeding season (Tables 2 and 3 ).

The better reproductive performance of cows weaned at 76 days post-calving is partially due to their higher weight gain $(\mathrm{P}<0.05)$ in the period between the two weaning ages and during the breeding seasons, resulting in better body condition. It must be noted that cows weaned at 148 days post-calving were kept in the study because they were able to get pregnant in the subsequent years. In addition, their body condition at calving, at the time of early weaning, and body weight at end of the breeding season were similar to the early-weaned cows (Tables 3 and 4), which allows us to believe that those cows have excellent genetic capacity to produce in this environment (Deese \& Koger, 1967).

There was a significant effect of the interaction between weaning age and year on calving interval. In the $2004 / 2005$ season, calving intervals were not different ( $P>0.05$ ) between weaning ages, but in the 2005/2006 season, cows weaned at 148 days post-calving presented shortened calving interval (Table 5).

These results are different from those obtained by Lobato \& Barcellos (1992), who observed that cows provided with better nutrition showed a shorter interval between calving and the first estrus post-calving, particularly when associated to better body condition. In the present study, the shorter calving intervals obtained in 2005/2006 are probably due to a reduction of 23 days in weaning age among the observation years. This resulted in a 39-day reduction in calving interval related to better nutritional conditions as compared to 2004/2005.

This is consistent with the findings by Short et al. (1972) and Montiel \& Ahuja (2005), who also mention that the presence of calf with the cow causes a significant increase in the duration of post-calving anestrus, and consequently, of the calving interval.

Almeida et al. (2002), studying early weaning at 91 days, as carried out in the first year of the present study, observed an average calving interval of 399.2 days, which is similar to the result of 397.4 days that was obtained in this study.

Table 5 - Pregnancy rates during the 2004/2005, 2005/2006, and 2006/2007 breeding seasons and calving intervals, according to weaning age

\begin{tabular}{|c|c|c|c|c|c|c|}
\hline \multirow{2}{*}{ Weaning age } & \multicolumn{3}{|c|}{ Pregnancy rate/breeding season, \% } & \multirow{2}{*}{ Mean } & \multicolumn{2}{|c|}{ Calving interval, days } \\
\hline & $2004 / 2005$ & $2005 / 2006$ & $2006 / 2007$ & & $2004 / 2005$ & $2005 / 2006$ \\
\hline Early weaning & $91.6(71) \mathrm{A}$ & $83.9(63)$ & $82.0(51)$ & $86.3 \mathrm{~A}$ & $398 \pm 2.2 \mathrm{a}$ & $368 \pm 2.5 b$ \\
\hline Conventional weaning & $41.2(70) \mathrm{B}$ & $72.0(28)$ & $88.3(18)$ & $55.5 \mathrm{~B}$ & $402 \pm 3.3 \mathrm{a}$ & $355 \pm 4.0 \mathrm{c}$ \\
\hline Mean & 66.4 & 77.9 & 85.1 & & $400 \pm 2.0$ & $361 \pm 2.6$ \\
\hline
\end{tabular}

a,b,c - For the same effect, means followed by different small letter are different $(\mathrm{P}<0.05)$ by the t-test.

A,B - Means in the same columns followed by different capital letter are different $(\mathrm{P}<0.05)$ by the Chi-Square test.

Numbers between brackets indicate the number of cows assessed per treatment within the same year. 
Those authors stated that this is not an optimal interval, because to obtain one calf/year, the required interval would be \pm 365 days, as verified in the second year of observation, when weaning age was reduced to 67 days.

Lobato et al. (2000), working with primiparous cows at 3 years of age grazing on improved pastures post-calving, during winter and spring, observed that the presence of the calf and lactation have negative effects on the reproductive indexes of the cows. When cows were submitted to early weaning or conventional weaning when calves were 70 or 176 days of age, calving intervals of 359.6 and 381.6 days, respectively, were obtained.

Not only nutrition determines the return of the cow to reproductive activity; the presence of the calf should also be highlighted. Working with improved pastures and obtaining high pregnancy rates $(89.47 \%)$, Lobato et al. (2000) showed that cows submitted to conventional weaning presented higher calving intervals, with a 16.6-day delay relative to the optimal interval of 365 days and a 22 -day delay relative to early-weaned cows.

Another factor associated to the observed increase in calving interval in the first year is the fact that cows were calving for the first time and had higher requirements as compared to mature cows. Cerdótes et al. (2004b) found shorter calving interval in old and mature cows weaned at 42 days post-calving, and these were the only groups of cows that presented calving intervals shorter than one year. Primiparous cows, despite of being maintained under good feeding conditions and weaned at 42 or 63 days postcalving, did not present calving intervals shorter than 365 days.

The interaction between weaning age and year influenced milk production (Table 6 ). The milk production of early-weaned cows was similar in 2005 and 2006, with 5.75 and 6.02 liters/day, respectively. However, milk production of the cows in the conventional weaning group increased $(\mathrm{P}<0.05)$ from 4.15 to 5.84 liters/day in 2005 and 2006, respectively.

The increase in milk production of the cows weaned at 148 days post-calving may be associated with age increase.

Table 6 - Milk production at the time of early weaning, according to weaning age and year

\begin{tabular}{lccc}
\hline \multirow{2}{*}{ Weaning age } & \multicolumn{2}{c}{ Milk production, 1} & \multirow{2}{*}{ Mean } \\
\cline { 2 - 3 } & 2005 & 2006 & \\
\hline Early weaning & $5.75 \pm 0.21 \mathrm{a}$ & $6.02 \pm 0.23 \mathrm{a}$ & $5.88 \pm 0.15$ \\
Conventional weaning & $4.15 \pm 0.32 \mathrm{~b}$ & $5.84 \pm 0.38 \mathrm{a}$ & $5.00 \pm 0.25$ \\
Mean & $4.95 \pm 0.19$ & $5.93 \pm 0.22$ & \\
\hline
\end{tabular}

$\mathrm{a}, \mathrm{b}$ - Means followed by different lines in the same column and in the same row ar different $(\mathrm{P}<0.05)$ by $\mathrm{t}$-test.
Studies that estimated milk production showed that the peak of milk production is achieved when cows become mature (Restle et al., 2001; Cerdótes et al., 2004a). The average milk production at the time of early weaning in the two studied years was 5.88 vs. 5.00 liters/day for early and conventionally-weaned cows, respectively. In 2005 and 2006 , milk production of cows weaned at 76 days postcalving was 38.6 and $3.0 \%$ higher, respectively, than that of cows weaned at 148 days post-calving. The higher production obtained in 2005 is due to the lower "wear" suffered by these cows in the previous year because calves were weaned earlier (62 days), allowing cows to achieve better conditions for the next pregnancy and lactation. Another factor influencing the low milk production of the conventionally weaned cows in 2005 is the fact that they were second-calf cows, therefore, first-calf growing heifers in 2004, staying with their calves longer than those in the early weaning group.

Quadros \& Lobato (1997) obtained values similar to those in the present study when studying primiparous cows at three years of age, and it was demonstrated that stocking rate and consequent forage availability influence milk production. Those authors observed values of 5.52 and 6.39 liters/day for cows maintained at stocking rates of 320 and $240 \mathrm{~kg}$ live weight/ha, respectively.

\section{Conclusions}

The early weaning of calves at 76 days of age, in average, allows cows to recover their body weight in the period after the early weaning and during the breeding season, providing better body condition at the time of conventional weaning, and consequently, significantly higher pregnancy rates as compared to cows that feed their calves up to 148 days of age. This effect is more pronounced in primiparous cows. As cows age, there is a cumulative effect of body weight and body condition, with consequences on their reproductive performance.

\section{Acknowledgements}

The authors thank Mr. Arizoli Gindri and his son João Carlos Gindri, owners of Fazenda Granja Itú, for funding this study and for allowing the use of their facilities and animals. We also thank Professor José Henrique Souza da Silva for helping with the statistical analyses, as well as Agricultural Engineer Paulo Rodrigo Guimarães dos Santos for helping us to collect the experimental data. 


\section{References}

ALMEIDA, L.S.P.; LOBATO, J.F.P.; Efeito da idade de desmame e suplementação no desenvolvimento de novilhas de corte. Revista Brasileira de Zootecnia. v.33, n.6, p.2086-2094, 2004 (supl.2).

ALMEIDA, L.S.P.; LOBATO, J.F.P.; SCHENKEL, F.S Data de desmame e desempenho reprodutivo de vacas de corte. Revista Brasileira de Zootecnia. v.31, n.3, p.1223-1229, 2002.

ASSOCIATION OF OFFICIAL ANALYTICAL CHEMITS AOAC. Official methods of analysis. 14.ed. Washington, D.C., 1984. $1141 \mathrm{p}$.

BARCELLOS, J.O.J.; LOBATO, J.F.P. Efeito da época de desmame no desenvolvimento de bezerros Hereford e suas cruzas. I. Peso ao nascer e ganho diário médio pré-desmama. Revista Brasileira de Zootecnia, v.21, n.1, p.137-149, 1992.

BERETTA, V.; LOBATO, J.F.P.; MiELitZ NETO, C.G.A. Produtividade e eficiência biológica de sistemas de produção de gado de corte de ciclo completo no Rio Grande do Sul. Revista Brasileira de Zootecnia, v.31, n.2, p.991-1001, 2002 (supl.).

CERDÓTES, L.; RESTlE, J.; ALVES FILHO, D.C. et al. Produção e composição do leite de vacas de quatro grupos genéticos submetidas a dois manejos alimentares no período de lactação Revista Brasileira de Zootecnia, v.33, n.3, p.610-622, 2004a.

CERDÓTES, L.; RESTLE, J.; BRONDANI. I.L. et al. Desempenho produtivo de vacas de quatro grupos genéticos submetidas a diferentes manejos alimentares, desmamadas aos 42 ou 63 dias de idade. Revista Brasileira de Zootecnia. v.33, n.3, p.585-596, 2004b

COSTA, A.M.; RESTLE, J.; MÜLLER, L. Influência da pastagem cultivada no desempenho reprodutivo de vacas com cria ao pé. Revista Centro de Ciências Rurais, v.11, n.4, p.187-200, 1981 .

CLUTTER, A.C.; NIELSEN, M.K. Effect of level of beef cow milk production on pre and post-weaning calf growth. Journal of Animal Science, v.64, n.5, p.1313-1322, 1987.

COBUCI, J.A.; EUCLYDES, R.F.; VERNEQUE, R.S. et al. Curva de lactação na raça guzerá. Revista Brasileira de Zootecnia, v.29, n.5, p.1332-1339, 2000.

DEESE, R.E.; KOGER, M. Heritability of reproduction. In: CUNHA, T.J.; WARNICK, A.C.; KOGER, M. (Eds.) Factors affecting calf crop. Gainesville: University of Florida, 1967, p. $232-238$.

EMPRESA BRASILEIRA DE PESQUISA AGROPECUÁRIA EMBRAPA. Sistema brasileiro de classificação de solos. Brasília: Embrapa Cerrados; Rio de Janeiro: Centro Nacional de Pesquisa de Solos, 1999. 412p.

FAGUNDES, J.I.B.; LOBATO, J.F.P.; SCHENKEL, F.S. Efeito de duas cargas animais em campo nativo e de duas idades a desmama no desempenho de vacas de corte primíparas. Revista Brasileira de Zootecnia, v.32, n.6, p.1722-1731, 2003 (supl. 1).

FREITAS, E.A.; LOPEZ, J.; PRATES, E.R. Produtividade de matéria seca, proteína digestível, e nutrientes digestíveis totais em pastagem nativa do Rio Grande do Sul. Anuário Técnico IPZFO, v.3, p.454-515, 1976.

GOTTSCHALL, C.S.; LOBATO, J.F.P. Comportamento reprodutivo de vacas de corte primíparas submetidas a três lotações em campo nativo. Revista Brasileira de Zootecnia, v.25, n.1, p.46-57, 1996.

LEMENAGER, R.P.; SMITH, W.H.; MARTIN, T.G. et al. Effects of winter and summer energy levels on heifers growth and reproductive performance. Journal of Animal Science, v.51, n.4, p.837-842, 1980.

LOBATO, J.F.P. A "vaca ideal" e seu manejo em sistemas de produção de ciclo curto. In: SIMPÓSIO DA CARNE BOVINA DA PRODUÇÃO AO CONSUMIDOR, 1., 2003, São Borja. Anais... Porto Alegre: UFRGS, 2003. p.09-46.
LOBATO, J.F.P.; ALMEIDA, L.S.P.; OSORIO, E.B. et al. Efeito da idade de desmame no desenvolvimento e nas características de carcaça de novilhos de corte. Revista Brasileira de Zootecnia, v.36, n.3, p.596-602, 2007.

LOBATO, J.F.P.; BARCELLOS, J.O.J. Efeito da utilização de pastagem melhorada no pós-parto e do desmame aos $100 \mathrm{ou}$ 180 days de idade no desempenho reprodutivo de vacas de corte. Revista Brasileira de Zootecnia, v.21, n.3, p.385-395, 1992.

LOBATO, J.F.P.; MÜlLER, A.; PEREIRA NETO, O.A. et al. Efeitos da idade à desmama sobre o desempenho reprodutivo de vacas de corte primíparas. Revista Brasileira de Zootecnia. v.29, n.6, p.2013-2018, 2000 (supl.1).

LOBATO, J.F.P.; VAZ, R.Z. O manejo do gado de cria no campo nativo. In: SIMPÓSIO DE FORRAGEIRAS E PRODUÇÃO ANIMAL - Ênfase: Importância e potencial produtivo da pastagem nativa, 1., 2006, Porto Alegre. Anais... Porto Alegre: ULBRA, 2006. p.77-114.

LOWMAN, B.G.; SCOTT, N.; SOMERVILle, S. Condition scoring bef cattle. Edinburgh: East of Scotland College of Agriculture. 1973. 8p.

MELTON, A.A.; RIGGS, J.K.; NELSON, L.A. et al. Milk production, composition and calf gains of Angus, Charolais and Hereford cows Journal of Animal Science, v.26, n.4, p.804-809, 1967.

MONTIEL, F.; AHUJA, C. Body condition and suckling as factors influencing the duration of postpartum anestrus in cattle: a review. Animal Reproduction Science, v.85, p.1-26, 2005.

MOOJEN, J.G.; RESTLE, J.; MOOJEN, E.L. Efeito da época de desmama e da pastagem no desempenho de vacas e terneiros de corte. 1. Desempenho das vacas. Ciência Rural, v.24, n.2, p.393-397, 1994.

MOREnO, J.A. Clima do Rio Grande do Sul. Porto Alegre: Secretaria da Agricultura. 1961. 41p.

NATIONAL RESEARCH COUNCIL - NRC. Nutrient requeriment of beef cattle. Washington D.C.: National Academy Press, 1996. $242 \mathrm{p}$

OSORO, K.O. Effecto de las principales variables de manejo sobre los parametros reproductivos en las vacas de cria. Producción y Sanidade Animales, v.1, n.1-2, p.87-111, 1986 (separata, 7).

PASCOAL, L.L.; VAZ, F.N. Desmame precoce aos sessenta days. In: RESTLE, J. (Ed.) Técnicas avançadas na recria e engorda de bovinos de corte. Santa Maria: 1997. p.36-50.

PILAU, A.; LOBATO, J.F.P. Desenvolvimento e desempenho reprodutivo de vacas primíparas aos $22 / 24$ meses de idade. Revista Brasileira de Zootecnia, v.38, n.4, p.728-736, 2009.

PÖTTER, L.; LOBATO, J.F.P.; MIELITZ NETO, C.G.A. Análises econômicas de modelos de produção com novilhas de corte primíparas aos dois, três ou quatro anos de idade. Revista Brasileira de Zootecnia, v.29, n.3, p.861-870, 2000.

PÖTTER, B.A.A.; LOBATO, J.F.P. Efeitos de carga animal, pastagem melhorada e idade de desmame no comportamento reprodutivo de vacas primíparas. Revista Brasileira de Zootecnia, v.33, n.1, p.192-202, 2004.

QUADROS, S.A.F.; LOBATO, J.F.P. Efeitos da lotação no comportamento reprodutivo de vacas de corte primíparas. Revista Brasileira de Zootecnia, v.25, n.1, p.22-35, 1996.

QUADROS, S.A.F.; LOBATO, J.F.P. Efeitos da lotação animal na produção de leite de vacas de corte primíparas e no desenvolvimento dos seus bezerros. Revista Brasileira de Zootecnia, v.26, n.1, p.27-33, 1997.

RESTLE, J.; PACHECO, P.S.; FREITAS, A.K. et al. Influência das taxas de ganho de peso pré-desmame das vacas e do tipo de pastagem no período pós-parto sobre a eficiência biológica de vacas e de bezerros de corte. Revista Brasileira de Zootecnia, v.36, n.4, p.874-880, 2007.

RESTlE, J.; PACHECO, P,S.; PASCOAL, L.L. et al. Efeito da pastagem, da produção e composição do leite no desempenho 
de bezerros de diferentes grupos genéticos. Revista Brasileira de Zootecnia, v.34, n.5, p.691-703, 2004.

RESTlE, J.; POLLI, V.A.; ALVES FILHO, D.C. et al. Desenvolvimento de bovinos de corte de diferentes grupos genéticos desmamados aos 3 ou 7 meses de idade. Revista Brasileira de Zootecnia, v.28, n.5, p.1023-1030, 1999.

RESTLE, J.; VAZ, R.Z.; ALVES FILHO, D.C. et al. Desempenho de vacas Charolês e Nelore desterneiradas aos três ou sete meses. Revista Brasileira de Zootecnia, v.30, n.2, p.499-507, 2001.

RIBEIRO, E.L.A.; RESTLE, J.; ROCHA, M.A. et al. Eficiência produtiva em vacas primíparas das raças Aberdeen Angus e Charolês. Revista Brasileira de Zootecnia, v.30, n.1, p.125-132, 2001.

ROVIRA, J.M. Reproducción y manejo de los rodeos de cria. Montivideo: Hemisfério Sur, 1974. 293p.

ROVIRA, J.M. Manejo nutritivo de los rodeos de cria em pastoreo. Montevideo: Hemisfério Sur, 1996. 288p.

SHORT, R.E.; BELLOWS, R.S.; MODDY, E.L. et al. Effects of suckling and mastectomy on bovine postpartum reproduction. Journal of Animal Science, v.74, n.2, p.70, 1972.
SHORT, R.E.; BELLOWS, R.A.; STAIGMILLER, R.B. et al. Physiological mechanisms controlling anestrus and infertility in post partum beef cattle. Journal of Animal Science, v.68, n.3, p.799-816, 1990.

SIMEONE, A.; LOBATO, J.F.P. Efeitos da lotação animal em campo nativo e do controle da amamentação no comportamento reprodutivo de vacas de corte primíparas. Revista Brasileira de Zootecnia, v.25, n.6, p.1216-1227, 1996.

SIMEONE, A.; LOBATO, J.F.P. Efeitos da carga animal em campo nativo e do controle da amamentação no desenvolvimento de bezerros mestiços até um ano de idade. Revista Brasileira de Zootecnia, v.27, n.1, p.179-185, 1998.

STATISTICAL ANALYSIS SYSTEM - SAS. SAS/STAT user's guide: statistics. 4.ed. Version 6. Cary: 1997. v.2, 943p.

VAZ, R.Z.; LOBATO, J.F.P. Efeito da idade de desmame no desenvolvimento de novilhas de corte até os 14/15 meses de idade. Revista Brasileira de Zootecnia, v.39, n.2, p.289-298, 2010.

VIEIRA, A.; LOBATO, J.F.P.; TORRES JR., R.A.A. et al. Fatores determinantes do desempenho reprodutivo de vacas Nelore na região dos cerrados do Brasil Central. Revista Brasileira de Zootecnia, v.34, n.6, p.2408-2416, 2005 (supl.). 